\title{
UPAYA MENINGKATKAN PERILAKU PRO SOSIAL MELALUI KONSELING KELOMPOK PADA SISWA KELAS XIIA2 SMA NEGERI I DOLOPO
}

\author{
Dra. Khusnul Khotimah ${ }^{1)}$ \\ 1) SMA Negeri 1 Dolopo Madiun
}

\begin{abstract}
ABSTRAK: Memperhatikan karakter dari siswa SMA maka perlakuan dan atau tindakan harus sesuai dengan tahap perkembangan mereka. Salah satu media yang tepat untuk memberikan perlakuan tersebut adalah melalui layanan bimbingan dan konseling. Bimbingan dan konseling sebagai salah satu unsur pendidikan yang memegang peranan strategis karena langsung bersentuhan dengan aspek pribadi siswa. Dari fakta yang ditemukan disekolah, pada siswa kelas XIIA2 SMA Negeri 1 Dolopo tahun pelajaran 2018/2019 masih terdapat beberapa siswa yang memiliki sikap/perilaku yang kurang sosial misalnya tidak peduli dengan teman,cuek,tidak mau kerjasama, interaksi antar siswa kurang tampak (membuat gang), siswa kurang memiliki perhatian/empati terhadap tamannya dsbnya,hal ini dapat menghambat proses pembelajaran. Metode penelitian yang dihunakan adalah penelitian tindakan kelas dengan sumber data berdasarkan angket dan observasi. Hasil penellitian yang didapatkan adalah bahwa konseling kelompok dapat meningkatkan perilaku pro sosial siswa SMAN I Dolopo, yang meliputi kemampuan untuk berinisiatif dalam memulai suatu hubungan interpersonal, kemampuan untuk membuka diri, kemampuan untuk bersikap asertif, kemampuan untuk memberikan dukungan emosional kepada individu lain dan, kemampuan mengelola dan mengatasi konflik.
\end{abstract}

Kata kunci : Perilaku Pro Sosial, Konseling, Bimbingan Kelompok.

ABSTRACT: Paying attention to the character of high school students, the treatment and/ or action must be in accordance with the stage of their development. One of the appropriate media to provide such treatment is through guidance and counseling services. Guidance and counseling as an element of education that plays a strategic role because it directly touch with the personal aspects of students. From the facts found at school, in class XIIA2 students of SMA Negeri 1 Dolopo in the 2018/2019 academic year there were still some students who had less social attitudes / behaviors such as not caring about friends, ignorant, did not want cooperation, interaction between students was less visible (making alley), students lack attention / empathy to the park etc., this can hamper the learning process. The research method used is classroom action research with data sources based on questionnaires and observations. The results obtained are that group counseling can improve the pro-social behavior of students at SMAN I Dolopo, which includes the ability to initiate interpersonal relationships, the ability to open up, the ability to be assertive, the ability to provide emotional support to other individuals and, the ability manage and resolve conflicts.

Keywords: Pro Social Behavior, Counseling, Group Counseling.

\section{PENDAHULUAN}

Perilaku sosial adalah perilaku yang relatif menetap yang diperlihatkan oleh individu di dalam berinteraksi dengan orang lain. Orang yang berperilakunya mencerminkan keberhasilan dalam proses sosialisasinya dikatakan sebagai orang yang sosial, sedangkan orang yang perilakunya tidak mencerminkan proses sosialisasi tersebut 
disebut non sosial. Yang termasuk ke dalam perilaku non sosial adalah perilaku a-sosial dan anti sosial.

Sebagai makhluk sosial, seorang individu sejak lahir hingga sepanjang hayatnya senantiasa berhubungan dengan individu lainnya atau dengan kata lain melakukan relasi interpersonal. Dalam relasi interpersonal itu ditandai dengan berbagai aktivitas tertentu, baik aktivitas yang dihasilkan berdasarkan naluriah semata atau justru melalui proses pembelajaran tertentu. Berbagai aktivitas individu dalam relasi interpersonal ini biasa disebut perilaku sosial.

Berkaitan dengan perubahan tingkah laku yang seharusnya terjadi pada siswa di kelas, guru sebagai pihak yang bertanggung jawab terhadap pengelolaan kelas, perlu melakukan berbagai upaya bimbingan terhadap siswa yang dinilai memiliki tingkah laku yang tidak sesuai dengan kelompoknya. Salah satu cara melakukan bimbingan dan pengarahan terhadap tingkah laku siswa adalah melalui penyampaian layanan bimbingan dan konseling.

Dari fakta yang ditemukan disekolah, pada siswa kelas XIIA2 SMA Negeri 1 Dolopo tahun pelajaran 2018/2019 masih terdapat beberapa siswa yang memiliki sikap/perilaku yang kurang sosial misalnya tidak peduli dengan teman,cuek,tidak mau kerjasama, interaksi antar siswa kurang tampak ( membuat gang), siswa kurang memiliki perhatian /empati terhadap tamannya dsbnya,hal ini dapat menghambat proses pembelajaran.

Berdasarkan temuaan fakta tersebut, penulis tertarik untuk mengadakan penelitian tentang "Upaya Meningkatkan Perilaku Pro Sosial Melalui Layanan Konseling Kelompok di Kelas XII A2 SMA Negeri 1 Dolopo tahun Pelajaran 2018/2019." Memperhatikan karakter dari siswa SMA maka perlakuan dan atau tindakan harus sesuai dengan tahap perkembangan mereka. Salah satu media yang tepat untuk memberikan perlakuan tersebut adalah melalui layanan bimbingan dan konseling. Bimbingan dan konseling sebagai salah satu unsur pendidikan yang memegang peranan strategis karena langsung bersentuhan dengan aspek pribadi siswa. Bimbingan dan konseling merupakan proses yang bersifat membantu individu mengubah perilaku dan pencapaian perkembangan pribadi secara optimal. Dengan demikian bimbingan dan konseling merupakan proses yang menunjang pelaksanaan program pendidikan di sekolah, karena program-program bimbingan dan konseling meliputi aspek-aspek tugas perkembangan individu, khususnya kematangan pendidikan dan karir, kematangan personal dan emosional, serta kematangan sosial. Salah satu bentuk dari layanan bimbingan dan konseling adalah konseling kelompok.

Rumusan masalah dalam penelitian ini adalah: Apakahkah konseling kelompok dapat meningkatkan perilaku pro sosial siswa kelas XIIA2 SMAN I Dolopo? 


\section{METODE PENELITIAN}

\section{Pendekatan Penelitian}

Penelitian ini menggunakan model penelitian tindakan (action research). Tim Pelatih Penelitian Tindakan UNY yang dikutip oleh Sujati (2000:2) mengartikan penelitian tindakan sebagai salah satu strategi pemecahan masalah dengan memanfaatkan tindakan nyata dan proses pengembangan kemampuan dalam mendeteksi dan memecahkan masalah. Selanjutnya Suharsimi Arikunto (2002:2) menyatakan bahwa dalam penelitian tindakan ini, peneliti melakukan sesuatu tindakan yang secara khusus diamati terus-menerus, dilihat plus-minusnya, kemudian diadakan pengubahan terkontrol sampai pada upaya maksimal dalam bentuk tindakan yang paling tepat.

\section{Subyek Penelitian}

Subyek penelitian diambil melalui purposive sampling yaitu pengambilan subyek bukan didasarkan atas strata, random, atau daerah tetapi didasarkan atas adanya tujuan tertentu. Subyek penelitian ini adalah siswa kelas XIIA2 di SMAN I Dolopo yang memiliki karakteristik sering menunjukkan sikap dan perilaku yang menggambarkan rendahnya perilaku pro sosial, indikasinya antara lain:

1. Siswa cenderung pasif dalam proses pembelajaran dan terlihat canggung saat maju di depan kelas.

2. Siswa kurang peduli dengan temannya.

3. Siswa sering gaduh sendiri di dalam kelas (tidak memberikan perhatian terhadap guru yang sedang mengajar).

4. Siswa kurang bisa mengontrol emosi, terlalu sensitif.

5. Interaksi antar siswa kurang tampak (membentuk gang).

6. Siswa kurang bisa menjalin komunikasi secara efektif, khususnya dengan guru.

7. Siswa kurang memberikan perhatian (empati) terhadap temannya.

\section{Teknik Pengumpulan Data}

Teknik pengumpulan data dalam penelitian ini meliputi:

1. Angket

2. Observasi

\section{Instrumen Penelitian}

a. Kisi-Kisi Angket

Kisi-kisi angket dalam penelitian ini adalah:

Tabel 1. Kisi-kisi Instrumen Perilaku Pro Sosial

\begin{tabular}{|l|l|l|}
\hline \multicolumn{1}{|c|}{ Variabel } & \multicolumn{1}{|c|}{ Indikator } & \multicolumn{1}{c|}{ Deskriptor } \\
\hline $\begin{array}{l}\text { Perilaku Pro } \\
\text { Sosial }\end{array}$ & $\begin{array}{l}\text { Kemampuan } \\
\text { berinisiatif } \\
\text { dalam memulai }\end{array}$ & $\begin{array}{l}\text { 1. Mengusulkan pada teman untuk melakukan aktivitas } \\
\text { bersama. }\end{array}$ \\
\hline
\end{tabular}




\begin{tabular}{|c|c|}
\hline $\begin{array}{l}\text { hubungan } \\
\text { interpersonal }\end{array}$ & $\begin{array}{l}\text { 2. Menjadi individu yang menyenangkan ketika } \\
\text { berhubungan dengan teman. }\end{array}$ \\
\hline \multirow{4}{*}{$\begin{array}{l}\text { Kemampuan } \\
\text { bersikap terbuka } \\
\text { (self disclosure) }\end{array}$} & $\begin{array}{l}\text { 1. Mempercayai teman untuk mengetahui hal-hal yang } \\
\text { bersifat pribadi dari diri kita. }\end{array}$ \\
\hline & $\begin{array}{l}\text { 2. Melepaskan ego kita untuk mempercayai teman } \\
\text { mengungkapkan pengalamannya. }\end{array}$ \\
\hline & $\begin{array}{l}\text { 3. Mengungkapkan secara terbuka kepada teman bahwa } \\
\text { kita menghargai dan menyayanginya. }\end{array}$ \\
\hline & $\begin{array}{l}\text { 4. Memberikan kesempatan pada teman untuk lebih } \\
\text { mengenal pribadi kita. }\end{array}$ \\
\hline \multirow{3}{*}{$\begin{array}{l}\text { Kemampuan } \\
\text { untuk bersikap } \\
\text { asertif }\end{array}$} & 1. Mempertahankan hak pribadi secara tegas. \\
\hline & 2. Menyampaikan pendapat-argumen secara jujur. \\
\hline & $\begin{array}{l}\text { 3. Meyakinkan teman untuk memahami gagasan/ide } \\
\text { kita. }\end{array}$ \\
\hline \multirow{3}{*}{$\begin{array}{l}\text { Kemampuan } \\
\text { memberikan } \\
\text { dukungan } \\
\text { emosional } \\
\text { (empati) }\end{array}$} & $\begin{array}{l}\text { 1. Memberi perhatian kepada teman yang sedang } \\
\text { mengalami masalah. }\end{array}$ \\
\hline & $\begin{array}{l}\text { 2. Memberikan rasa nyaman saat berhubungan dengan } \\
\text { teman. }\end{array}$ \\
\hline & $\begin{array}{l}\text { 3. Memberi keyakinan pada teman untuk menyelesaikan } \\
\text { tanggung jawabnya. }\end{array}$ \\
\hline \multirow{3}{*}{$\begin{array}{l}\text { Kemampuan } \\
\text { mengatasi } \\
\text { konflik } \\
\text { interpersonal }\end{array}$} & $\begin{array}{l}\text { 1. Tidak membiarkan konflik yang muncul semakin } \\
\text { memanas. }\end{array}$ \\
\hline & 2. Menjadi penengah ketika ada teman yang berkonflik. \\
\hline & 3. Tidak memaksakan kehendak kepada teman. \\
\hline
\end{tabular}

Setiap pernyataan dalam skala kecakapan interpersonal dilengkapi empat pilihan jawaban yaitu selalu (SL), sering (SR), jarang (J) dan tidak pernah (TP). Skor untuk skala kecakapan interpersonal yang positif secara berurutan adalah 4, 3, 2, 1. Untuk skala kecakapan interpersonal yang negatif masing-masing diberi skor 1, 2, 3, 4 .

b. Kisi-Kisi observasi

Kisi-kisi observasi dalam penelitian ini adalah;

Tabel 2. Kisi-kisi Observasi

\begin{tabular}{|l|l|l|}
\hline Variabel & Indikator & Deskriptor \\
\hline \multirow{3}{*}{$\begin{array}{l}\text { Perilaku Pro } \\
\text { Sosial }\end{array}$} & $\begin{array}{l}\text { Kemampuan } \\
\text { berinisiatif }\end{array}$ & 1. Aktif menyampaikan gagasan/ide \\
\cline { 2 - 3 } & $\begin{array}{l}\text { Kemampuan } \\
\text { bersikap terbuka }\end{array}$ & 1. Ketepatan gagasan/ide dengan konteks masalah \\
\cline { 3 - 3 } & & $\begin{array}{l}\text { 1. Menjalin kerjasama dalam kelompok. } \\
\text { disampaikan }\end{array}$ \\
\hline
\end{tabular}




\begin{tabular}{|c|c|}
\hline \multirow{2}{*}{$\begin{array}{l}\text { Kemampuan } \\
\text { untuk bersikap } \\
\text { asertif }\end{array}$} & 2. Mempertahankan gagasan/ide secara baik. \\
\hline & 3. Tidak mudah terpengaruh gagasan/ide teman \\
\hline \multirow{2}{*}{$\begin{array}{l}\text { Kemampuan } \\
\text { memberikan } \\
\text { dukungan } \\
\text { emosional }\end{array}$} & 1. Membantu teman yang gagal \\
\hline & $\begin{array}{l}\text { 2. Memberi perhatian saat teman menyampaikan } \\
\text { gagasan/ide }\end{array}$ \\
\hline \multirow{3}{*}{$\begin{array}{l}\text { Kemampuan } \\
\text { mengatasi } \\
\text { konflik }\end{array}$} & 1. Tidak otoriter-memonopoli permainan/diskusi. \\
\hline & 2. Menjadi penengah saat terjadi silang gagasan/ide. \\
\hline & 3. Tenang saat ide/gagasan ditolak. \\
\hline
\end{tabular}

\section{Teknik Analisis Data}

a. Analisis Data Kuantitatif

Untuk mengetahui perilaku pro sosial dengan instrumen skala Likert, maka penentuan kategori kecenderungan dari tiap-tiap variabel didasarkan pada norma atau ketentuan kategori. Kategori tersebut menurut Sutrisno Hadi (2000: 159) sebagai berikut:

1. Mean ideal $+1,5$ SD ke atas

$=$ Tinggi

2. Mean ideal sampai dengan mean ideal $+1,5 \mathrm{SD}=$ Sedang

3. Mean ideal - 1, 5 SD sampai dengan mean ideal = Kurang

4. Mean ideal - 1, 5 SD ke bawah = Rendah

b. Analisis data Kualitatif

Untuk menguji keabsahan data, peneliti akan memanfaatkan derajat kepercayaan dengan menggunakan teknik triangulasi. Dalam penelitian ini teknik triangulasi yang digunakan adalah teknik yang memanfaatkan sumber dan penyidik atau peneliti. Realisasi dari rencana penggunaan teknik ini ialah dibuat satu tim penelitian yang masing-masing akan ditugasi untuk mengumpulkan data yang sama pada subyek yang berbeda. Selanjutnya peneliti akan membandingkan data hasil (pengolahan) angket perilaku pro sosial dengan data hasil observasi.

\section{HASIL DAN PEMBAHASAN}

\section{Pelaksanaan Penelitian Tindakan}

\section{a. Siklus 1}

Hasil tindakan siklus 1 dalam penelitian ini dapat dilihat dari hasil post test dan pengamatan. Pelaksanaan konseling kelompok pada siklus 1 secara umum sudah terlaksana dengan baik. Berikut hasil penelitian setelah dilaksanakannya siklus 1 : 
Tabel 3. Hasil Post Test I

\begin{tabular}{|c|c|c|}
\hline Nama Siswa & Skor Post Test I & Kategori \\
\hline RSW & 85 & Tinggi \\
\hline WPL & 80 & Sedang \\
\hline WPA & 87 & Tinggi \\
\hline SA & 90 & Tinggi \\
\hline FW & 75 & Sedang \\
\hline SL & 80 & Sedang \\
\hline WA & 78 & Sedang \\
\hline DN & 90 & Tinggi \\
\hline MRS & 79 & Sedang \\
\hline IRA & 88 & Tinggi \\
\hline RKA & 70 & Sedang \\
\hline SAP & 77 & Sedang \\
\hline
\end{tabular}

Berdasarkan hasil tindakan dan monitoring siklus I peneliti melakukan refleksi. Peran monitoring dalam penelitian menurut Depdikbud (1999) adalah untuk mengenali dan mengevaluasi dua hal, yaitu:

1) Monitoring proses, yaitu apakah pelaksanaan tindakan telah sesuai dengan apa yang direncanakan. Pada dasarnya pelaksanaan konseling kelompok telah berjalan sesuai dengan prosedur perencanaan. Akan tetapi interaksi-dinamika kelompok yang terjadi kurang begitu tampak. Masih dijumpai siswa yang terlalu pasif dalam menyampaikan gagasan dan atau idenaya. Saat pelaksanaan tindakan tidak jarang dijumpai siswa yang melamun, berbicara adi luar topik bahasan dan lain sebagainya.

2) Monitoring hasil, yaitu telah mulai adanya peningkatan, perubahan positif menuju ke pencapaian tujuan diadakannya atau dilaksanakannya tindakan. Monitoring hasil lebih ditekankan pada perolehan hasil post test. Dari perolehan skor post test bisa disimpulkan jika kecakapan interpersonal siswa mengalami peningkatan. Rata-rata skor yang diperoleh saat pre test adalah 69, 25 dan saat post test I skor rata-ratanya adalah 81,5 , ini berarti ada peningkatan sebesar 12 poin.

\section{b. Siklus II}

Kegiatan diakhiri dengan mengadakan post test 2 untuk mengetahui tingkat perilaku pro sosial mereka setelah dilakukan tindakan kedua.

Tabel 4. Hasil Post Test II

\begin{tabular}{|c|c|c|}
\hline Nama Siswa & Skor Post Test II & Kategori \\
\hline RSW & 95 & Tinggi \\
\hline WPL & 92 & Tinggi \\
\hline WPA & 90 & Tinggi \\
\hline SA & 99 & Tinggi \\
\hline FW & 90 & Tinggi \\
\hline
\end{tabular}




\begin{tabular}{|c|c|c|}
\hline SL & 81 & Sedang \\
\hline WA & 88 & Tinggi \\
\hline DN & 96 & Tinggi \\
\hline MRS & 89 & Tinggi \\
\hline IRA & 94 & Tinggi \\
\hline RKA & 78 & Sedang \\
\hline SAP & 87 & Tinggi \\
\hline
\end{tabular}

Monitoring hasil ini difokuskan pada perolehan skor post test. Dari skor post test II yang diperoleh siswa, terlihat peningkatan kecakapan interpersonal yang signifikan. Ratarata skor post test II adalah 129, ada peningkatan sebesar 14 poin jika dibandingkan dengan post test siklus I. Hasil observasi juga selaras dengan hasil post test. Secara singkat asumsi tersebut berdasar pada beberapa hal, antara lain: (1) siswa sudah aktif dalam menyampaikan pendapat; (2) siswa mampu menerima perbedaan pendapat dan tidak reaksionis ketika mendapat kritikan; (3) siswa memiliki usaha untuk meyakinan agar pendapatnya bisa diterima; (4) siswa cukup lugas menjawab pertanyaan.

\section{Hasil Observasi}

Berdasarkan observasi yang telah dilaksanakan maka direduksi dalam dtabel berikut ini:

Tabel 4.8

Reduksi Hasil Observasi

\begin{tabular}{|c|c|c|}
\hline \multirow[t]{2}{*}{ Nama } & \multicolumn{2}{|c|}{ Perilaku dan Sikap Siswa } \\
\hline & Siklus I & Siklus II \\
\hline RSW & $\begin{array}{l}\text { - Cukup aktif menyampaikan } \\
\text { pendapat. } \\
\text { - Kurang mampu menerima } \\
\text { pendapat yang berbeda. } \\
\text { - Cenderung memaksakan } \\
\text { kehendak-otoriter. } \\
\text { - Kurang memberi perhatian } \\
\text { saat ada teman yang } \\
\text { berpendapat. } \\
\text { - Mampu memberikan } \\
\text { keyakinan saat berargumen. }\end{array}$ & $\begin{array}{l}\text { - Aktif menyampaikan pendapat. } \\
\text { - Mulai mampu menerima } \\
\text { pendapat yang berbeda. } \\
\text { - Tidak otoriter/memaksakan } \\
\text { pendapat kepada teman. } \\
\text { - Cukup memberi perhatian saat } \\
\text { ada teman yang berpendapat. } \\
\text { - Mampu memberikan } \\
\text { keyakinan saat berargumen. }\end{array}$ \\
\hline WPL & $\begin{array}{l}\text { - Kurang memperhatikan } \\
\text { teman yang menyampaikan } \\
\text { pendapat. } \\
\text { - Pasif menyampaikan } \\
\text { pendapat. }\end{array}$ & $\begin{array}{l}\text { - Memperhatikan teman yang } \\
\text { menyampaikan pendapat. } \\
\text { - Cukup aktif menyampaikan } \\
\text { pendapat. } \\
\text { - Tidak melempar } \\
\text { tanggungjawab kepada teman }\end{array}$ \\
\hline
\end{tabular}




\begin{tabular}{|c|c|c|}
\hline & $\begin{array}{l}\text { - Cenderung mencela saat ada } \\
\text { teman yang berbeda } \\
\text { pendapat. }\end{array}$ & \\
\hline WPA & $\begin{array}{l}\text { - Mampu menyenaraikan } \\
\text { gagasaaaan dengan konteks } \\
\text { masalah. } \\
\text { - Aktif menyampaikan } \\
\text { pendapat. } \\
\text { - Cukup mampu memberi } \\
\text { keyakinan pada teman saat } \\
\text { berargumen. } \\
\text { - Cenderung otoriter, } \\
\text { memaksakan kehendak. } \\
\text { - Memberi perhatian saat ada } \\
\text { teman yang menyampaikan } \\
\text { pendapat. } \\
\text { - Menjadi penengah saat ada } \\
\text { teman yang silang pendapat. }\end{array}$ & $\begin{array}{l}\text { - Mampu menyenaraikan } \\
\text { gagasaaaan dengan konteks } \\
\text { masalah. } \\
\text { - Aktif menyampaikan pendapat. } \\
\text { - Cukup mampu memberi } \\
\text { keyakinan pada teman saat } \\
\text { berargumen. } \\
\text { - Memberi perhatian saat ada } \\
\text { teman yang menyampaikan } \\
\text { pendapat. } \\
\text { - Menjadi penengah saat ada } \\
\text { teman yang silang pendapat. }\end{array}$ \\
\hline SA & $\begin{array}{l}\text { - Aktif berpendapat tapi } \\
\text { cenderung otoriter. } \\
\text { - Reaksionis saat mendapat } \\
\text { kritikan/pendapat disanggah. } \\
\text { - Memberi perhatian saat } \\
\text { teman menyampaikan } \\
\text { pendapat. } \\
\text { - Cukup mampu meyakinkan } \\
\text { teman untuk memahami } \\
\text { pendapat yang disampaikan. } \\
\text { - Pendapat yang diutarakan } \\
\text { cukup sesuai dengan topik } \\
\text { masalah. }\end{array}$ & $\begin{array}{l}\text { - Aktif menyampaikan pendapat. } \\
\text { - Bersikap tenang saat mendapat } \\
\text { kritikan/pendapat disanggah. } \\
\text { - Memberi perhatian saat teman } \\
\text { menyampaikan pendapat. } \\
\text { - Mampu meyakinkan teman } \\
\text { untuk memahami pendapat } \\
\text { yang disampaikan. } \\
\text { - Pendapat yang diutarakan } \\
\text { cukup sesuai dengan topik } \\
\text { masalah. }\end{array}$ \\
\hline FW & $\begin{array}{l}\text { - Memperhatikan teman yang } \\
\text { menyampaikan pendapat. } \\
\text { - Mau membantu teman yang } \\
\text { kesulitan mengerjakan tugas. } \\
\text { - Pasif dalam menyampaikan } \\
\text { pendapat tapi memiliki } \\
\text { usaha yang keras untuk } \\
\text { menyelesaikan tugas. } \\
\text { - Tidak otoriter dalam } \\
\text { kelompok, mampu } \\
\text { bekerjasama. }\end{array}$ & $\begin{array}{l}\text { - Memperhatikan teman yang } \\
\text { menyampaikan pendapat. } \\
\text { - Mau membantu teman yang } \\
\text { kesulitan mengerjakan tugas. } \\
\text { - Aktif dalam menyampaikan } \\
\text { pendapat. } \\
\text { - Tidak otoriter dalam } \\
\text { kelompok, mampu } \\
\text { bekerjasama dalam } \\
\text { menyelesaikan tugas. }\end{array}$ \\
\hline SL & $\begin{array}{l}\text { - Cukup aktif menyampaikan } \\
\text { pendapat akan tetapi } \\
\text { bahasanya cenderung keras. }\end{array}$ & - Aktif menyampaikan pendapat. \\
\hline
\end{tabular}




\begin{tabular}{|c|c|c|}
\hline & $\begin{array}{l}\text { - Tidak mudah menerima } \\
\text { pendapat yang berbeda. } \\
\text { - Kurang mampu meyakinkan } \\
\text { teman untuk memahami } \\
\text { pendapat yang disampaikan } \\
\text { karena cara bicara yang } \\
\text { kurang tenang. } \\
\text { - Cenderung keras dalam } \\
\text { mempertahankan argum }\end{array}$ & $\begin{array}{l}\text { - Resolusi konflik semakin baik( } \\
\text { tenang dalam mempertahankan } \\
\text { pendapat). } \\
\text { - Memperhatikan teman yang } \\
\text { menyampaikan pendapat. }\end{array}$ \\
\hline WA & $\begin{array}{l}\text { - Menerima pendapat teman } \\
\text { tanpa memberi } \\
\text { sanggahan/masukan. } \\
\text { - Memberi perhatian saat } \\
\text { teman menyampaikan } \\
\text { pendapat. } \\
\text { - Kurang aktif dalam } \\
\text { menyampaikan pendapat } \\
\text { tapi serius saat mengerjakan } \\
\text { tugas. } \\
\text { - Bersikap tenang saat ada adu } \\
\text { argumen. } \\
\end{array}$ & $\begin{array}{l}\text { - Memberi perhatian saat teman } \\
\text { menyampaikan pendapat. } \\
\text { - Mengikuti jawaban tanpa ada } \\
\text { sanggahan. } \\
\text { - Mulai aktif dalam } \\
\text { menyampaikan pendapat. } \\
\text { - Mampu bersikap tenang dalam } \\
\text { kelompok. }\end{array}$ \\
\hline $\mathrm{DN}$ & $\begin{array}{l}\text { - Aktif menyampaikan } \\
\text { pendapat. } \\
\text { - Mampu menyenaraikan } \\
\text { pendapat dengan topik } \\
\text { masalah. } \\
\text { - Mampu meyakinkan teman } \\
\text { untuk memahami pendapat } \\
\text { yang disampaikan. } \\
\text { - Mampu mempertahankan } \\
\text { pendapat dengan tenang. } \\
\text { - Memperhatikan teman yang } \\
\text { menyampaikan pendapat. } \\
\text { - Kurang tenang saat pendapat } \\
\text { disanggah/mendapat kritik. }\end{array}$ & $\begin{array}{l}\text { - Aktif menyampaikan pendapat. } \\
\text { - Tidak mudah terpengaruh } \\
\text { jawaban teman. } \\
\text { - Mampu mempertahankan } \\
\text { pendapat yang disampaikan } \\
\text { saat ada yang menyanggah. } \\
\text { - Memberi perhatian kepada } \\
\text { teman yang menyempaikan } \\
\text { pendapatnya. }\end{array}$ \\
\hline MRS & $\begin{array}{l}\text { - Sering memberi kritik } \\
\text { kepada teman yang } \\
\text { mengutarakan pendapat. } \\
\text { - Cukup aktif dalam } \\
\text { berpendapat. } \\
\text { - Cenderung otoriter, kurang } \\
\text { mampu menjalin kerjasama } \\
\text { dalam kelompok. }\end{array}$ & $\begin{array}{l}\text { - . Bersikap tenang saat } \\
\text { mendapat teguran. } \\
\text { - Aktif menyampaikan pendapat, } \\
\text { akan tetapi bahasanya } \\
\text { cenderung keras. } \\
\text { - Memperhatikan saat ada teman } \\
\text { yang menyaampaikan } \\
\text { pendapatnya. }\end{array}$ \\
\hline
\end{tabular}




\begin{tabular}{|c|c|c|}
\hline & $\begin{array}{l}\text { - Kurang memperhatikan } \\
\text { teman yang menyampaikan } \\
\text { pendapat. }\end{array}$ & \\
\hline IRA & $\begin{array}{l}\text { - Aktif menyampaikan } \\
\text { pendapat akan tetapi terlalu } \\
\text { confidance. } \\
\text { - Tidak mudah menerima } \\
\text { pendapat teman, apalagi } \\
\text { yang berbeda. } \\
\text { - Cukup memperhatikan } \\
\text { teman yang menyampaikan } \\
\text { pendapat. } \\
\text { - Terlalu sering memberi } \\
\text { sanggahan pada teman yang } \\
\text { berpendapat. }\end{array}$ & $\begin{array}{l}\text { - Aktif menyampaikan pendapat. } \\
\text { - Tidak terlalu dominan dalam } \\
\text { kelompok. } \\
\text { - Memperhatikan teman yang } \\
\text { mengutarakan pendapat. } \\
\text { - Resolusi konflik semakin baik, } \\
\text { tidak reaksionis saat pendapat } \\
\text { disanggah/diberi kritikan. }\end{array}$ \\
\hline RKA & $\begin{array}{l}\text { - Menerima pendapat tanpa } \\
\text { memberikan sanggahan. } \\
\text { - Kurang mampu } \\
\text { mempertahankan pendapat } \\
\text { saat ada yang } \\
\text { menyanggahnya/tidak } \\
\text { menyetujui. } \\
\text { - Memberi perhatian saat } \\
\text { teman mengutarakan } \\
\text { pendapat. } \\
\text { - Cenderung pasif dalam } \\
\text { berpendapat. }\end{array}$ & $\begin{array}{l}\text { - Aktif menyampaikan pendapat } \\
\text { dan mampu bersikap } \\
\text { kondusif/tidak gaduh. } \\
\text { - Tetap tenang ketika pendapat } \\
\text { mendapat sanggahan/ditolak. } \\
\text { - Memperhatikan teman yang } \\
\text { menyampaikan pendapatnya. }\end{array}$ \\
\hline SAP & $\begin{array}{l}\text { - Aktif menyampaikan } \\
\text { pendapat tapi nada bicara } \\
\text { cenderung tinggi. } \\
\text { - Sering menyanggah } \\
\text { pendapat yang berbeda. } \\
\text { - Mampu meyakinkan teman } \\
\text { untuk memahami pendapat } \\
\text { yang disampaikan. } \\
\text { - Mampu menjadi penengah } \\
\text { saat ada adu argumen } \\
\text { diantara teman. }\end{array}$ & $\begin{array}{l}\text { - Aktif menyampaikan pendapat. } \\
\text { - Mampu mempertahankan } \\
\text { pendapat secara baik. } \\
\text { - Memberi sanggahan jika } \\
\text { pendapat tidak sama. } \\
\text { - Tidak bersikap reaksionis saat } \\
\text { pendapat disanggah/diberi } \\
\text { masukan. } \\
\text { - Memperhatikan teman yang } \\
\text { menyampaikan pendapatnya. }\end{array}$ \\
\hline
\end{tabular}




\section{KESIMPULAN DAN SARAN}

\section{Kesimpulan}

Berdasarkan hasil penelitian dan pembahasan yang telah diuraikan, maka dapat disimpulkan bahwa konseling kelompok dapat meningkatkan perilaku pro sosial siswa SMAN I Dolopo, yang meliputi kemampuan untuk berinisiatif dalam memulai suatu hubungan interpersonal, kemampuan untuk membuka diri, kemampuan untuk bersikap asertif, kemampuan untuk memberikan dukungan emosional kepada individu lain dan, kemampuan mengelola dan mengatasi konflik.

Hasil penelitian menunjukkan pelaksanaan konseling kelompok dapat meningkatkan salah satu kompetensi dari siswa, yang erat kaitannya dengan ranah sosial yakni perilaku pro sosial. Melalui konseling kelompok, siswa dapat belajar untuk berbuat secara konstruktif sehingga nantinya akan mampu mengembangkan kemampuan berfikir serta komunikasi. Bagi guru pembimbing, hasil yang didapatkan ini tidak hanya memberikan wawasan baru dari sebuah konsep, lebih dari itu guru pembimbing akan mampu mengaplikasikannya guna mencapai efektivitas dari layanan bimbingan dan konseling.

\section{Saran}

1. Bagi Guru Pembimbing

Guru pembimbing sebagai "kunci sentral" pelaksanaan layanan bimbingan dan konseling di sekolah, seyogyanya memahami dan mampu mengaplikasikan materi/jenis dan teknik dalam menyelenggarakan konseling kelompok, sehingga nantinya efektivitas dari hasil penelitian ini dapat terus berlangsung.

2. Bagi Kepala Sekolah

Kepala sekolah yang merupakan pimpinan tertinggi harus memberikan kesempatan kepada guru pembimbing untuk lebih mendalami materi/jenis teknik dalam menyelenggarakan konseling kelompok. Hal ini sebagai upaya konkrit dalam memberikan dukungan kepada guru pembimbing dalam meningkatkan efektivitas layanan $\mathrm{BK}$.

\section{DAFTAR RUJUKAN}

Adi W Gunawan. (2005). Born To Be Genius. Jakarta: Gramedia Pustaka Utama.

Ahmad Juntika Nurihsan. (2005). Strategi Layanan Bimbingan dan Konseling. Bandung: Refika Aditama.

Andi Mappiarre. (1982). Psikologi Remaja. Surabaya: Usaha Nasional.

Bimo Walgito. (2005). Bimbingan dan Konseling (Studi dan Karir). Yogyakarta: Andi Offset. 
Campbell, at.al. (2002). Multiple Intelligences Metode Terbaru Melesatkan Kecerdasan. Depok: Inisiasi Press.

Chaplin, J.P. (2000). Kamus Lengkap Psikologi (terjemahan Kartono, K) Jakarta: Pt Raja Grafindo Persada.

Danardono. (1997). Kompetensi Kecerdasan Intepersonal Mahasiswa Ditinjau Dari Status Keiukutsertaan Pada Kegiatan Pecinta Alam. Skripsi. Yogyakarta: Fakultas Psikologi UGM.

Dedi Mulyana. (2004). Metodologi Penelitian Kualitatif. Bandung: PT. Remaja Rosdakarya.

Djumhur dan Moh. Surya. (1975). Bimbingan dan Penyuluhan di Sekolah.

Gazda, G. M. (1997). Group Counseling A Developmental Approach. Boston: Allyn and Baron.

Goleman, D. (1996). Emotional Intelligence. New York: Bantam Books.

Kemmis \& McTaggart, R (eds). (1988). The Action Research Planner. Melbourne : Deakin University Press.

Kunandar. (2008). Langkah Mudah Penelitian Tindakan Kelas (sebagai Pengembangan Profesi Guru). Jakarta : Rajawali Press.

Moh. Nazir. (1999). Metode Penelitian. Jakarta: Ghalia Indonesia.

Prayitno. (1995). Layanan Bimbingan dan Konseling Kelompok (Dasar dan Profil). Jakarta: Ghalia Indonesia.

Sugiyono. 1999. Metode Penelitian Administrasi. Bandung: Alfabeta.

Suharsimi Arikunto. (2002). Prosedur Penelitian Suatu Pendekatan Praktek (Edisi Revisi). Jakarta: Rineka Cipta.

Supriyadi Saputro. (2000). Strategi Pembelajaran (Bahan Sajian Program Pendidikan Akta Mengajar). Depdiknas Universitas Negeri Malang.

Sutrisno Hadi. (2000). Metodologi Research I. Yogyakarta: Andi Offset.

Suwarsih Madya. (2006). Teori dan Praktek Penelitian Tindakan. Bandung: Alfabeta.

Winkel. (1991). Bimbingan dan Konseling di Institusi Pendidikan. Jakarta: Gramedia Widiasarana. 